\title{
Synthesis and antileishmanial evaluation of some 2,3-disubstituted-4(3H)-quinazolinone derivatives
}

\author{
Yihenew Simegniew Birhan ${ }^{1 *}$, Adnan Ahmed Bekhit ${ }^{2}$ and Ariaya Hymete ${ }^{3}$
}

\begin{abstract}
Background: Leishmaniasis is a neglected tropical parasitic diseases affecting millions of people around the globe. Quinazolines are a group of compounds with diverse pharmacological activities. Owing to their promising antileishmanial activities, some 3-aryl-2-(substitutedstyryl)-4(3H)-quinazolinones were synthesized in good yields (65.2\% to $86.4 \%)$.

Results: The target compounds were synthesized by using cyclization, condensation, and hydrolysis reactions. The structures of the synthesized compounds were determined using elemental microanalysis, infrared (IR), and proton nuclear magnetic resonance ('H NMR). The in vitro antileishmanial activities of the synthesized compounds were evaluated using Leishmania donovani strain. All the synthesized compounds displayed appreciable antileishmanial activities ( $\left(C_{50}\right.$ values, 0.0128 to $\left.3.1085 \mu \mathrm{g} / \mathrm{ml}\right)$ as compared to the standard drug miltefosine $\left(I C_{50}=3.1911 \mu \mathrm{g} / \mathrm{ml}\right)$. (E)-2-(4-chlorostyryl)-3-p-tolyl-4(3H)-quinazolinone (7) is the compound with the most promising antileishmanial activities $\left(I C_{50}=0.0128 \mu \mathrm{g} / \mathrm{ml}\right)$ which is approximately 4 and 250 times more active than the standard drugs amphotericin B deoxycholate $\left(\mathrm{IC}_{50}=0.0460 \mu \mathrm{g} / \mathrm{ml}\right)$ and miltefosine $\left(\mathrm{IC}_{50}=3.1911 \mu \mathrm{g} / \mathrm{ml}\right)$, respectively.

Conclusions: The results obtained from this investigation indicate that the synthesized and biologically evaluated quinazoline compounds showed promising antileishmanial activities and are good scaffolds for the synthesis of different antileishmanial agents.
\end{abstract}

Keywords: Quinazolinones; Leishmania; Antileishmanial activities

\section{Background}

Leishmanisis is a neglected tropical disease resulting from infection of macrophages by obligate intracellular parasites of the genus Leishmania [1-3]. It is a public health problem in at least 88 countries with an estimated 350 million people at risk. The estimated global prevalence of all forms of the disease is 12 million. Every year, 1.5 to 2 million new cases and 70,000 deaths occur due to cutaneous leishmaniasis (CL). In addition, 500,000 new cases and 59,000 deaths from visceral leishmaniasis (VL) occur annually [4]. The number of cases of leishmaniasis is increasing globally due to Leishmania/HIV co-infection $[5,6]$, international travel, and migration of immigrants and refugees from endemic regions $[7,8]$.

The prophylactic treatment of leishmaniasis mainly rely on vector and reservoir control [9-11]. Control of

\footnotetext{
*Correspondence: yihenews@gmail.com

'Department of Chemistry, Natural and Computational Science College,

Debre Markos University, Debre Markos, Ethiopia

Full list of author information is available at the end of the article
}

reservoir host and vector is difficult due to high coast, operational difficulties, and frequent relapses in the host [12]. Although considerable effort has been made to produce vaccine candidates for the treatment of leishmaniasis, there is no vaccine against any form of human leishmaniasis yet [13-17].

Pentavalent antimonials $\left(\mathrm{Sb}^{\mathrm{V}}\right)$ have been used for the treatment of leishmania infections. Unfortunately, in many parts of the world, the parasite has become resistant to $\mathrm{Sb}^{\mathrm{V}}$ [18]. Treatment failure to sodium stibogluconate (SSG) is observed in Eastern Sudan [19] and in Tigray, Northern Ethiopia [20]. Recent reports showed that pentamidine also developed resistance as well as difficulties in treating patients with Leishmania/HIV co-infection [21].

Combination chemotherapy has improved prospects for decreasing the emergence of drug resistance, increasing activity, and reducing required doses and thereby toxic side effects. In the previous study, WR 279,396 (a topical formulation containing 15\% paromomycin and $0.5 \%$ gentamicin) was found to be safe and effective against CL 
caused by Leishmania major [22]. In addition, AmBisomeparomomycin is the most cost-effective combination among miltefosine-paromomycin and AmBisome-miltefosine [23]. So far, no combination chemotherapy has been used in treatment programs, except paromomycin/SSG [24].

Tremendous quinazoline derivatives are synthesized in the past two decades, using different synthetic pathways [25-30], due to their diverse pharmacological activities [31-36] including antileishmanial activities [37-40]. These reports indicate that several quinazolines were synthesized and tested for their antileishmanial activities, with the aim of discovering alternative chemotherapeutic agents for the development of new antileishmanials. Promising antileishmanial activities were observed in some 4aminoquinazoline [37], indolo[2,1-b] quinazoline-6,12-dione [38], and 2,3-disubstituted-4(3H)-quinazolinone derivatives $[39,40]$. As part of the efforts to discover less toxic and more effective drug analogues for the treatment of leishmaniasis, we synthesized some 2,3-disubstituted-4 $(3 H)$-quinazolinones and tested their in vitro antileishmanial activities.

\section{Methods}

\section{Chemicals and reagents}

Anthranilic acid, acetic anhydride, aniline, $p$-toluidine, $o$-toluidine, acetone, dimethylsulfoxide, anhydrous zinc chloride, $p$-chlorobenzaldehyde, $p$-nitrobenzaldehyde, $p$ hydroxybenzaldehyde, chloroform, absolute ethanol, resazurin sodium salt, anhydrous petroleum ether, distilled water, iodine, $\mathrm{HCl}$, and $\mathrm{KOH}$ were used in the study.

\section{Instruments and apparatuses}

Melting points were determined in open capillaries using electro-thermal 9100 melting point apparatus and were uncorrected. Infrared (IR) spectra in nujol were recorded with the SHIMADZU 8400SP FT-IR spectrophotometer (Shimadzu Corporation, Nakagyo-ku, Kyoto, Japan), and proton nuclear magnetic resonance $\left({ }^{1} \mathrm{H}\right.$ NMR) spectral data were performed on Bruker Avance DMX400 FT-NMR spectrometer (Bruker, Billerica, MA, USA) using tetramethyl silane (TMS) as internal standard. Silica gel TLC plates of $0.25-\mathrm{mm}$ thickness were used in the study.

\section{Experimental animals and strains}

Swiss albino male mice of weight 20 to $32 \mathrm{~g}$ and age 6 to 8 weeks (for acute toxicity test) were obtained from Biomedical Laboratory, Department of Biology, Faculty of Science, AAU. Leishmania donovani isolate used in this study was obtained from Leishmania Diagnosis and Research Laboratory (LDRL) culture bank, School of Medicine, AAU.

\section{Culture medium and conditions}

RPMI-1640, 10\% heat-inactivated fetal calf serum (HIFCS), $1 \%$ penicillin-streptomycin, and $1 \% \mathrm{~L}$-glutamine were supplied to make a complete culture medium. The $L$. donovani isolate was grown first on Novy-MacNealNicolle (NNN) medium and then in tissue culture flasks containing RPMI-1640 medium supplemented with 10\% HIFCS and $1 \% 100 \mathrm{IU}$ penicillin $/ \mathrm{ml}-100 \mu \mathrm{g} / \mathrm{ml}$ streptomycin solution at $22^{\circ} \mathrm{C}$ for promastigotes.

\section{Reference drugs}

Miltefosine/hexadecylphosphocholine (AG Scientific, San Diego, CA, USA) and amphotericin B deoxyhcholate (Fungizone ${ }^{\circ}$, ER Squibb, Middlesex, UK) were employed as reference drugs in the in vitro antileishmanial activity testing of the synthesized compounds.

\section{Preparation of stock and working solutions}

Stock solutions of $10 \mathrm{mg} / \mathrm{ml}$ of the synthesized compounds were prepared by dissolving each compound in DMSO. Stock solutions were diluted using complete RPMI to obtain aliquots of $10 \mu \mathrm{g} / \mathrm{ml}$. Then, threefold serial dilution with complete RPMI gave the final six working concentrations $(10,3.33,1.11,0.37,0.12$, and $0.04 \mu \mathrm{g} / \mathrm{ml})$ of each of the synthesized compounds. Amphotericin B deoxycholate and miltefosine, which were used as a positive control for comparison of the antileishmanial activities of the test compounds, were also made in threefold serial dilutions. All the prepared drugs were stored at $-20^{\circ} \mathrm{C}$ and retrieved only during use [41].

\section{In vitro antileishmanial activity}

In a 96-well microtiter plate, $100 \mu \mathrm{l}$ of each of the seven threefold serial dilutions of synthesized compounds were added in triplicate wells. Then, $100 \mu \mathrm{l}$ of suspension of parasites $\left(3.0 \times 10^{6}\right.$ promastigotes $/ \mathrm{ml}$ of $L$. donovani $)$ was added in duplicate. Some of the wells contained only the parasites which served as a positive control. The media and DMSO alone acted as a negative control. The contents of the plates were then maintained in humidified atmosphere at $22^{\circ} \mathrm{C}$ under $5 \% \mathrm{CO}_{2}$.

After $68 \mathrm{~h}$ of incubation, $10 \mu \mathrm{l}$ of fluorochrome resazurin solution $(12.5 \mathrm{mg}$ dissolved in $100 \mathrm{ml}$ of distilled water) was added into each well. The fluorescence intensity was measured after a total incubation period of $72 \mathrm{~h}$ using Victor3 Multilabel Counter (PerkinElmer, Waltham, MA, USA), at an excitation wavelength of $530 \mathrm{~nm}$ and emission wavelength of $590 \mathrm{~nm}$ [42]. The $\mathrm{IC}_{50}$ values were evaluated from sigmoidal dose-response curves using GraphPad Prism 5.0 software (GraphPad Software, Inc., San Diego, CA, USA).

\section{In vivo acute toxicity test}

The oral acute toxicity of compound 7 that exhibited promising antileishmanial activity was investigated using male Swiss albino mice (approximately $20 \mathrm{~g}$ each) following reported methods [43]. The experimental animals were 
divided into six groups (containing six mice per group) and fasted overnight. Groups 1-5 received compound 7 suspended in a vehicle containing $1 \%$ gum acacia, in doses of 10, 50,100, 200, and $300 \mathrm{mg} / \mathrm{kg}$, respectively. The sixth group received vehicle containing $1 \%$ gum acacia (served as a control group) at a maximum dose of $1 \mathrm{ml} / 100 \mathrm{~g}$ of body weight by oral route. The mice were observed closely for $24 \mathrm{~h}$ with special attention to the first $4 \mathrm{~h}$. Acute toxicity signs were checked in the test mice.

\section{Statistical analysis}

The $\mathrm{IC}_{50}$ values for in vitro promastigotes assay of synthesized compounds were evaluated from sigmoidal dose-response curves using computer software GraphPad Prism 5.0.

\section{Results and discussion}

\section{Chemistry of the synthesized compounds}

Synthesis of the target compounds involved the formation of 2-5 and $\mathbf{1 0}$ as intermediates. It was accomplished using nucleophilic reaction, nucleophilic with ring opening and closing, condensation reaction, and hydrolysis reactions. The target compounds are synthesized in a good yield, which ranged from $65.2 \%$ to $86.4 \%$ (Table 1). All the synthesized compounds were readily soluble in DMSO and chloroform except compound $\mathbf{1 2}$ which is readily soluble in acetone. Spectral data (IR and ${ }^{1} \mathrm{H}$ NMR) of the synthesized compounds were in full agreement with the proposed structures.

\section{Biological activity testing results}

\section{In vitro antileishmanial activity of the synthesized compounds}

The antipromastigote activities of the synthesized compounds and the standard antileishmanial drugs (amphotericin B deoxycholate and miltefosine) were evaluated using the clinical isolate of $L$. donovani strain. The $\mathrm{IC}_{50}$ of the synthesized and reference drugs were evaluated from fluorescence characteristic of AlamarBlue ${ }^{\circ}$ (resazurin) (Trek Diagnostic Systems, Inc., Cleveland, OH, USA) which is soluble, stable in culture medium, non-toxic to cells, and does not affect the secretary abilities of cells [44]. The test works as a cell viability and proliferation indicator through the conversion of resazurin to resorufin via reduction. The amount of fluorescence produced is proportional to the number of living cells $[45,46]$.

The quinazolinone derivatives synthesized were shown to have good antileishmanial activity which was in line with the previous reports [37-40]. All the tested compounds exhibited better antileishmanial activity than the standard drug miltefosine as shown in Table 2. Among them, compound 7 was found to have a very promising antileishmanial activity with an $\mathrm{IC}_{50}$ value of $0.0128 \mu \mathrm{g} / \mathrm{ml}$ which was 250 times superior than miltefosine $(3.1911 \mu \mathrm{g} /$ $\mathrm{ml})$. Compounds $\mathbf{8}$ and $\mathbf{1 1}$ were 30 times more active than miltefosine. Compounds $\mathbf{6}$ and $\mathbf{1 2}$ were 10 times and twice more active than miltefosine, respectively. Compounds 9 and $\mathbf{1 3}$ were as active as miltefosine.

All the synthesized compounds except compound 7 displayed weak antileishmanial activities as compared to amphotericin B deoxycholate. Better antipromastigote activity was observed for (E)-2-(4-chlorostyryl)-3- $p$-tolyl$4(3 H)$-quinazolinone (7) with an $\mathrm{IC}_{50}$ value of 0.0128 $\mu \mathrm{g} / \mathrm{ml}$ which is four times higher than the standard drug amphotericin $\mathrm{B}$ deoxycholate with an $\mathrm{IC}_{50}$ value of $0.0128 \mu \mathrm{g} / \mathrm{ml}$. (E)-2-(4-chlorostyryl)-3-p-tolyl-4(3H)-quinazolinone (7) was found to be 4 times more active than amphotericin B deoxycholate and 250 times more active than miltefosine.

\section{Oral acute toxicity study}

Compound (E)-2-(4-chlorostyryl)-3-p-tolyl-4(3H)-quinazolinone (7) was observed to be devoid of any inherent acute toxicities at a maximum dose of $300 \mathrm{mg} / \mathrm{kg}$.

\section{Experimental}

\section{Synthesis of target compounds}

The synthesis of target compounds, 3-aryl-2-(substitutedstyryl)-4(3H)-quinazolinones (6-9 and 11-13), was achieved using cyclization, condensation, and hydrolysis reactions. It involved the synthesis of acetanthranil (2methyl-3,1-benzoxazin-4-one (2)) and 3-aryl-2-methyl-4

Table 1 Physical constants and percent yield of the synthesized compounds

\begin{tabular}{llllll}
\hline Test compound & Molecular formula & Molecular weight $(\mathbf{g} / \mathbf{m o l})$ & \% yield & Melting point $\left({ }^{\circ} \mathbf{C}\right)$ & $\boldsymbol{R}_{\mathbf{f}}$ values $\left[\mathbf{C H C l} / \mathbf{C}_{6} \mathrm{H}_{\mathbf{6}}(\mathbf{9 : 1})\right]$ \\
\hline $\mathbf{6}$ & $\mathrm{C}_{22} \mathrm{H}_{17} \mathrm{ClN}_{2} \mathrm{O}$ & 360.85 & 68.3 & 201 to 203 & 0.520 \\
$\mathbf{7}$ & $\mathrm{C}_{23} \mathrm{H}_{19} \mathrm{ClN}_{2} \mathrm{O}$ & 374.87 & 65.2 & 189 to 191 & 0.577 \\
$\mathbf{8}$ & $\mathrm{C}_{23} \mathrm{H}_{18} \mathrm{~N}_{3} \mathrm{O}_{3}$ & 384.41 & 74.8 & 214 to 216 & 0.422 \\
$\mathbf{9}$ & $\mathrm{C}_{23} \mathrm{H}_{18} \mathrm{~N}_{3} \mathrm{O}_{3}$ & 384.41 & 76.2 & 235 to 237 & 0.642 \\
$\mathbf{1 1}$ & $\mathrm{C}_{26} \mathrm{H}_{24} \mathrm{~N}_{2} \mathrm{O}_{4}$ & 428.49 & 86.4 & 151 to 153 & 0.781 \\
$\mathbf{1 2}$ & $\mathrm{C}_{22} \mathrm{H}_{18} \mathrm{~N}_{2} \mathrm{O}_{2}$ & 342.40 & 80.3 & 298 to 300 & 0.524 \\
$\mathbf{1 3}$ & $\mathrm{C}_{24} \mathrm{H}_{22} \mathrm{~N}_{2} \mathrm{O}_{3}$ & 386.45 & 82.2 & 196 to 198 & 0.711 \\
\hline
\end{tabular}


Table 2 Antipromastigote activity $\left(\mathrm{IC}_{50}\right)$ of the synthesized compounds

\begin{tabular}{lll}
\hline Test compounds & $\mathbf{I C}_{\mathbf{5 0}}$ values $(\boldsymbol{\mu g} / \mathbf{m l})$ & $\mathbf{I C}_{\mathbf{5 0}}$ values $(\mathbf{n g} / \mathbf{m l})$ \\
\hline $\mathbf{6}$ & 0.3014 & 301.40 \\
$\mathbf{7}$ & 0.0128 & 12.80 \\
$\mathbf{8}$ & 0.1085 & 108.50 \\
$\mathbf{9}$ & 2.7017 & $2,701.70$ \\
$\mathbf{1 1}$ & 0.1086 & 108.60 \\
$\mathbf{1 2}$ & 1.6472 & $1,647.20$ \\
$\mathbf{1 3}$ & 3.1085 & $3,108.50$ \\
Miltefosine & 3.1911 & $3,191.10$ \\
Amphotericin B & 0.0460 & 46.00 \\
\hline
\end{tabular}

$\mathrm{IC}_{50}$ : effective concentration required to achieve $50 \%$ growth inhibition (in $\left.\mu \mathrm{g} / \mathrm{ml}\right)$.

(3H)-quinazolinones (3-5) as intermediates (Scheme 1). The details of each reactions and reaction conditions, the summarized characteristic stretching and bending IR vibration frequencies, the elemental microanalysis, and the ${ }^{1} \mathrm{H}$ NMR chemical shift data for each of the synthesized target compounds are given below.
General procedure for the synthesis of 2-methyl-3,1-benzoxazin-4-one (2)

A solution of anthranillic acid (1) (10 g, $0.073 \mathrm{~mol})$ in acetic anhydride $(25 \mathrm{ml})$ was heated under reflux for $1 \mathrm{~h}$. The precipitate formed on cooling was filtered and the excess acetic anhydride was washed with anhydrous petroleum ether, where upon a solid mass is obtained. This solid mass (2), without purification, was used for subsequent reaction [47].

\section{General procedure for the synthesis of}

\section{3-aryl-2-methyl-4(3H)-quinazolinones (3-5)}

A mixture of 2-methyl-3,1-benzoxazin-4-one (2) (3 g, $0.017 \mathrm{~mol}$ ) and equimolar amounts of aromatic amines (aniline, $p$-toluidine, and $o$-toluidine, respectively) was heated under reflux at $190^{\circ} \mathrm{C}$ for $5 \mathrm{~h}$. The dark sticky mass formed were cooled and recrystallized from ethanol to yield compounds 3-5, respectively [48].

\section{General procedure for the synthesis of}

3-aryl-2-(4-chlorostyryl)-4(3H)-quinazolinones (6 and 7)

To a solution of 3 or 4 ( $0.5 \mathrm{~g}$ each) in acetic anhydride $(10 \mathrm{ml})$, an equimolar amount of $p$-chlorobenzaldehyde

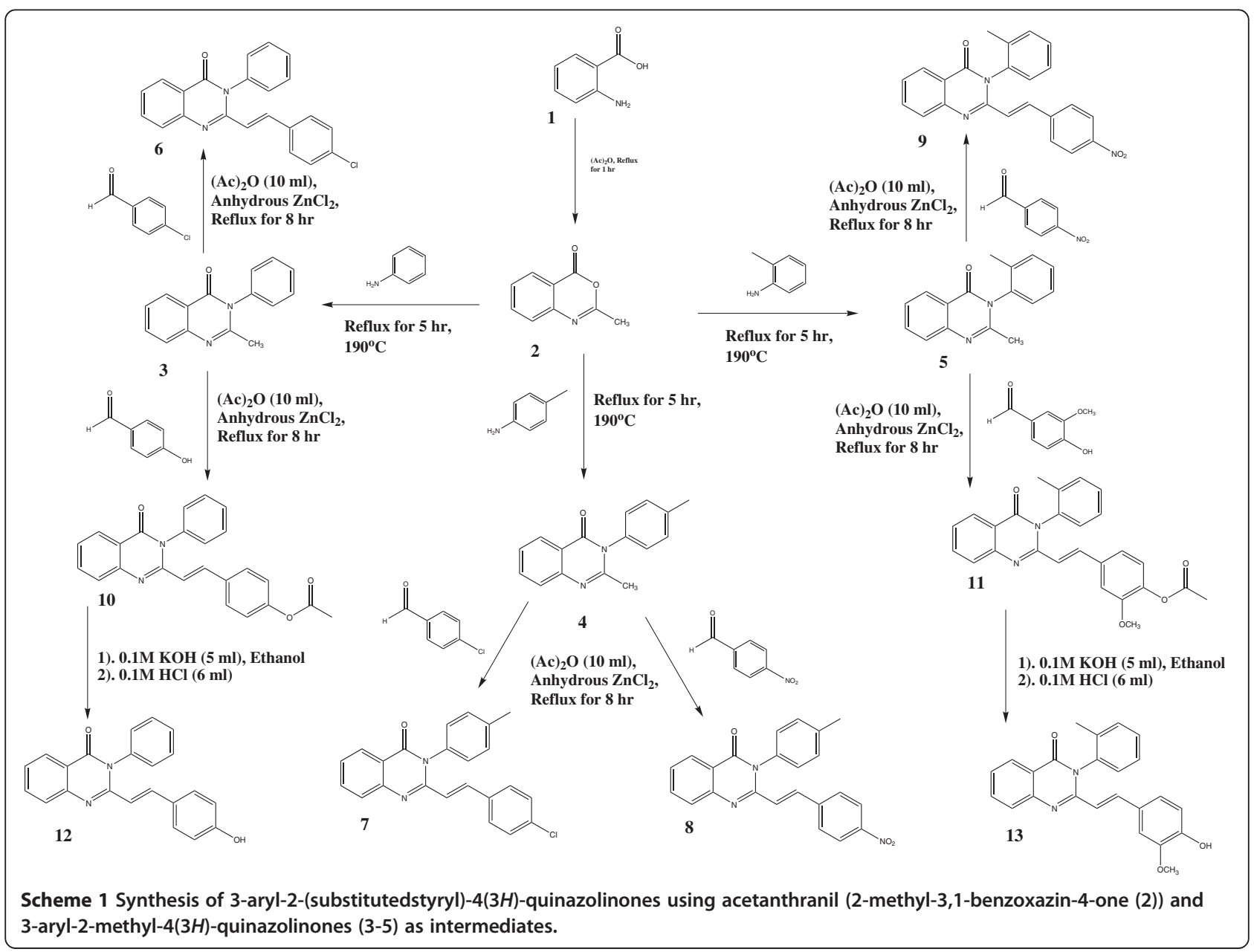


was added in the presence of $10 \mathrm{mg}$ of anhydrous zinc chloride as a catalyst. The reaction mixture was heated under reflux for $8 \mathrm{~h}$, cooled, and poured into ice-cooled water. The solid products formed (6 or 7 ) were filtered, dried, and recrystallized from chloroform/ethanol (2:1) [49].

\section{(E)-2-(4-chlorostyryl)-3-phenylquinazolin-4(3H)-one (6)}

IR (Nujol) $\left(\mathrm{cm}^{-1}\right): 1,682(\mathrm{C}=\mathrm{O}), 1,597(\mathrm{C}=\mathrm{N})$, and 1,224 (C-Cl). ${ }^{1} \mathrm{H}$ NMR $\left(\mathrm{CDCl}_{3}\right) \delta(\mathrm{ppm}): 6.33(d, 1 \mathrm{H}, J=15.49$ $\mathrm{Hz}$, vinyl- $\left.\mathrm{C}_{2} \mathrm{H}\right), 7.23(d, 2 \mathrm{H}, J=8.53 \mathrm{~Hz}$, 4-chlorophenyl $\left.\mathrm{C}_{3,5} \mathrm{H}\right), 7.28\left(d, 2 \mathrm{H}, J=8.47 \mathrm{~Hz}\right.$, 4-chlorophenyl $\left.\mathrm{C}_{2,6} \mathrm{H}\right)$, 7.34 $\left(d, 2 \mathrm{H}, J=6.82 \mathrm{~Hz}\right.$, phenyl $\left.\mathrm{C}_{2,6} \mathrm{H}\right), 7.45$ to $7.49(m$, $1 \mathrm{H}$, quina- $\left.\mathrm{C}_{6} \mathrm{H}\right), 7.58$ to $7.63\left(m, 3 \mathrm{H}\right.$, phenyl $\left.\mathrm{C}_{3,4,5} \mathrm{H}\right)$, 7.75 to $7.79\left(m, 2 \mathrm{H}\right.$, quina- $\left.\mathrm{C}_{7,8} \mathrm{H}\right), 7.91(d, 1 \mathrm{H}, J=15.47$ $\mathrm{Hz}$, vinyl- $\left.\mathrm{C}_{1} \mathrm{H}\right), 8.29\left(d, 1 \mathrm{H}, J=7.95 \mathrm{~Hz}\right.$, quina- $\left.\mathrm{C}_{5}\right)$. Anal. calcd. for $\mathrm{C}_{22} \mathrm{H}_{17} \mathrm{ClN}_{2} \mathrm{O}: \mathrm{C}, 73.23 ; \mathrm{H}, 4.75 ; \mathrm{Cl}, 9.83 ; \mathrm{N}$, 7.76. Found: C, 73.64; H, 4.92; Cl, 10.22; N, 7.54.

\section{(E)-2-(4-chlorostyryl)-3-p-tolylquinazolin-4(3H)-one (7)}

IR (Nujol) $\left(\mathrm{cm}^{-1}\right): 1,682(\mathrm{C}=\mathrm{O}), 1,597(\mathrm{C}=\mathrm{N})$, and 1,224 (C-Cl). ${ }^{1} \mathrm{H}$ NMR $\left(\mathrm{CDCl}_{3}\right) \delta$ (ppm): $2.5(s, 3 \mathrm{H}, p$-tolyl $\left.\mathrm{CH}_{3}\right), 6.42\left(d, 1 \mathrm{H}, J=15.70 \mathrm{~Hz}\right.$, vinyl- $\left.\mathrm{C}_{2} \mathrm{H}\right), 7.21(d, 2 \mathrm{H}$, 4-chlorophenyl $\left.\mathrm{C}_{3,5} \mathrm{H}\right), 7.26$ to $7.32\left(m, 4 \mathrm{H}, p\right.$-tolyl $\mathrm{C}_{2,3,5,6}$ $\mathrm{H}), 7.40\left(d, 2 \mathrm{H}, 4\right.$-chlorophenyl $\left.\mathrm{C}_{2,6} \mathrm{H}\right), 7.47$ to $7.51(\mathrm{~m}$, $1 \mathrm{H}$, quina- $\left.\mathrm{C}_{6} \mathrm{H}\right), 7.79$ to $7.83\left(\mathrm{~m}, 2 \mathrm{H}\right.$, quina- $\left.\mathrm{C}_{7,8} \mathrm{H}\right), 7.93$ $\left(d, 1 \mathrm{H}\right.$, vinyl- $\left.\mathrm{C}_{1} \mathrm{H}\right), 8.32\left(d, 1 \mathrm{H}\right.$, quina- $\left.\mathrm{C}_{5} \mathrm{H}\right)$. Anal. calcd. for $\mathrm{C}_{23} \mathrm{H}_{19} \mathrm{ClN}_{2} \mathrm{O}: \mathrm{C}, 73.69 ; \mathrm{H}, 5.12 ; \mathrm{Cl}, 9.46 ; \mathrm{N}, 7.47$. Found: C, 73.98; H, 5.38; Cl, 9.35; N, 7.21.

\section{General procedure for the synthesis of} 3-aryl-2-(4-nitrostyryl)-4(3H)-quinazolinones (8 and 9)

To a solution of $\mathbf{4}$ or 5 ( $0.5 \mathrm{~g}$ each) in acetic anhydride $(10 \mathrm{ml})$, an equimolar amount of $p$-nitrobenzaldehyde was added in the presence of $10 \mathrm{mg}$ of anhydrous zinc chloride as a catalyst. The reaction mixture was heated under reflux for $8 \mathrm{~h}$, cooled, and poured into ice-cooled water. The solid products formed (8 or $\mathbf{9}$ ) were filtered, dried, and recrystallized from chloroform/ethanol (2:1) [49].

\section{(E)-2-(4-nitrostyryl)-3-p-tolylquinazolin-4(3H)-one (8)}

IR (Nujol) $\left(\mathrm{cm}^{-1}\right)$ : 1,684 $(\mathrm{C}=\mathrm{O}), 1,593(\mathrm{C}=\mathrm{N}), 1,556$ and 1,377 $\left(\mathrm{NO}_{2}\right) .{ }^{1} \mathrm{H}$ NMR $\left(\mathrm{CDCl}_{3}\right) \delta(\mathrm{ppm}): 2.5(s, 3 \mathrm{H}$, $p$-tolyl $\left.\mathrm{CH}_{3}\right), 6.56\left(d, 1 \mathrm{H}, J=15.52 \mathrm{~Hz}\right.$, vinyl- $\left.\mathrm{C}_{2} \mathrm{H}\right), 7.21$ $\left(d, 2 \mathrm{H}, J=8.19 \mathrm{~Hz}, p\right.$-tolyl $\left.\mathrm{C}_{3,5} \mathrm{H}\right), 7.41(d, 2 \mathrm{H}, J=7.97$ $\mathrm{Hz}, p$-tolyl $\left.\mathrm{C}_{2,6} \mathrm{H}\right), 7.46$ to $7.53(m, 3 \mathrm{H}$, 4-nitrophenyl $\mathrm{C}_{2,6}$ and quina- $\left.\mathrm{C}_{6}\right), 7.77$ to $7.81\left(\mathrm{~m}, 2 \mathrm{H}\right.$, quina- $\left.\mathrm{C}_{7,8}\right), 8.00$ $\left(d, 1 \mathrm{H}, J=15.52 \mathrm{~Hz}\right.$, vinyl- $\left.C_{1}\right), 8.19(d, 2 \mathrm{H}, J=8.74 \mathrm{~Hz}$, 4-nitrophenyl $\left.C_{3,5}\right), 8.30\left(d, 1 \mathrm{H}, J=8.01 \mathrm{~Hz}\right.$, quina- $\left.C_{5}\right)$. Anal. calcd. for $\mathrm{C}_{23} \mathrm{H}_{18} \mathrm{~N}_{3} \mathrm{O}_{3}$ : C, 71.86; H, 4.72; N, 10.93 . Found: C, 72.12; H, 4.35; N, 11.10 .

\section{(E)-2-(4-nitrostyryl)-3-o-tolylquinazolin-4(3H)-one (9)}

IR (Nujol) $\left(\mathrm{cm}^{-1}\right): 1,682(\mathrm{C}=\mathrm{O}), 1,593(\mathrm{C}=\mathrm{N}), 1,556$ and 1,377 $\left(\mathrm{NO}_{2}\right) .{ }^{1} \mathrm{H}$ NMR $\left(\mathrm{CDCl}_{3}\right) \delta(\mathrm{ppm}): 2.17(s, 3 \mathrm{H}, o-$ tolyl $\left.\mathrm{CH}_{3}\right), 6.47\left(d, 1 \mathrm{H}, J=15.66 \mathrm{~Hz}\right.$, vinyl- $\left.\mathrm{C}_{2} \mathrm{H}\right), 7.25$ $\left(d, 1 \mathrm{H}, J=7.91 \mathrm{~Hz}, o\right.$-tolyl $\left.\mathrm{C}_{3} \mathrm{H}\right), 7.44$ to $7.46(m, 3 \mathrm{H}$, 4-nitrophenyl $\mathrm{C}_{2,6}$ and o-tolyl $\mathrm{C}_{6} \mathrm{H}$ ), 7.47 to 7.58 (m, $3 \mathrm{H}, o$-tolyl $\mathrm{C}_{4,5}$ and quina- $\left.\mathrm{C}_{6} \mathrm{H}\right), 7.82$ to $7.89(\mathrm{~m}, 2 \mathrm{H}$, quina- $\left.\mathrm{C}_{7,8} \mathrm{H}\right), 8.05\left(d, 1 \mathrm{H}, J=15.56 \mathrm{~Hz}\right.$, vinyl- $\left.\mathrm{C}_{1} \mathrm{H}\right)$, $8.19\left(d, 2 \mathrm{H}, J=8.73 \mathrm{~Hz}\right.$, 4-nitrophenyl $\left.\mathrm{C}_{4,6} \mathrm{H}\right), 8.36(d, 1 \mathrm{H}$, $J=8.25 \mathrm{~Hz}$, quina- $\mathrm{C}_{5} \mathrm{H}$ ). Anal. calcd. for $\mathrm{C}_{23} \mathrm{H}_{18} \mathrm{~N}_{3} \mathrm{O}_{3}: \mathrm{C}$, 71.86; H, 4.72; N, 10.93. Found: C, 71.68; H, 4.93; N, 11.24.

\section{General procedure for the synthesis of 3-aryl-2- \\ (4-acetylatedstyryl)-4(3H)-quinazolinones (10)}

To a solution of $3(0.5 \mathrm{~g})$ in acetic anhydride $(10 \mathrm{ml})$, an equimolar amount of $p$-hydroxybenzaldehyde was added. Anhydrous zinc chloride $(10 \mathrm{mg})$ is added as a catalyst. The reaction mixture is heated under reflux for $8 \mathrm{~h}$, cooled, and poured into ice-cooled water. The solid product formed (10) was filtered, dried, and recrystallized from ethanol [49].

\section{General procedure for the synthesis of}

3-aryl-2-(4-acetylatedstyryl)-4(3H)-quinazolinones (11)

To a solution of $5(0.5 \mathrm{~g})$ in acetic anhydride $(10 \mathrm{ml})$, an equimolar amount of vanillin was added. Anhydrous zinc chloride $(10 \mathrm{mg})$ is added as a catalyst. The reaction mixture is heated under reflux for $8 \mathrm{~h}$, cooled, and poured into ice-cooled water. The solid product (11) was filtered, dried, and recrystallized from ethanol [49].

4-\{(1E)-2-[-3,4-dihydro-3-(2-methylphenyl)-4-oxoquinazoline2-yl)]vinyl\}-2-methoxyphenyl acetate (11)

IR (Nujol) $\left(\mathrm{cm}^{-1}\right): 1,761(\mathrm{C}=\mathrm{O}), 1,682(\mathrm{C}=\mathrm{O}), 1,634$ $(\mathrm{C}=\mathrm{N}), 1,260$ and $1,149(\mathrm{C}-\mathrm{O}-\mathrm{C}) .{ }^{1} \mathrm{H}$ NMR $\left(\mathrm{CDCl}_{3}\right) \delta$ (ppm): $2.15\left(s, 3 \mathrm{H}\right.$, phenylacetate $\left.\mathrm{CH}_{3}\right), 2.33(s, 3 \mathrm{H}$, $o$-tolyl $\left.\mathrm{CH}_{3}\right), 3.80\left(s, 3 \mathrm{H}\right.$, methoxy $\left.-\mathrm{O}-\mathrm{CH}_{3}\right), 6.27$ (d, $1 \mathrm{H}, J=15.44 \mathrm{~Hz}$, vinyl- $\left.\mathrm{C}_{2} \mathrm{H}\right), 6.88$ to $6.93(m, 2 \mathrm{H}, 2-$ methoxyphenyl $\left.\mathrm{C}_{3,5} \mathrm{H}\right), 6.98(d, 1 \mathrm{H}, J=8.12 \mathrm{~Hz}, 2$ methoxyphenyl $\left.\mathrm{C}_{6} \mathrm{H}\right), 7.24\left(d, 1 \mathrm{H}, J=7.52 \mathrm{~Hz}, o\right.$-tolyl $C_{3}$ $\mathrm{H}), 7.42$ to $7.53\left(m, 4 \mathrm{H}, o\right.$-tolyl $\mathrm{C}_{4,5,6} \mathrm{H}$ and quina- $\left.\mathrm{C}_{6} \mathrm{H}\right)$, 7.82 to $7.83\left(m, 2 \mathrm{H}\right.$, quina- $\left.\mathrm{C}_{7,8} \mathrm{H}\right), 7.96(d, 1 \mathrm{H}, J=15.48$ $\mathrm{Hz}$, vinyl- $\left.\mathrm{C}_{1} \mathrm{H}\right), 8.34\left(d, 1 \mathrm{H}, J=7.88 \mathrm{~Hz}\right.$, quina- $\left.\mathrm{C}_{5} \mathrm{H}\right)$. Anal. calcd. for $\mathrm{C}_{26} \mathrm{H}_{24} \mathrm{~N}_{2} \mathrm{O}_{4}$ : C, 72.88; H, 5.65; N, 6.54. Found: C, 73.11; H, 5.89; N, 6.42.

General procedure for the synthesis of 3-aryl-2-(4-deacetylatedstyryl)-4(3H)-quinazolinones (12 and 13)

Subsequent treatment of $\mathbf{1 0}$ and $\mathbf{1 1}$ with $0.1 \mathrm{M}$ alcoholic $\mathrm{KOH}(5 \mathrm{ml})$ in the presence of ethanol followed by 0.1 $\mathrm{M} \mathrm{HCl}(6 \mathrm{ml})$ gave the corresponding 4-hydroxyl containing compounds 12 and $\mathbf{1 3}$ after recrystallization from ethanol [49].

(E)-2-(4-hydroxystyryl)-3-phenylquinazolin-4(3H)-one (12) IR (Nujol) $\left(\mathrm{cm}^{-1}\right): 3,290(\mathrm{OH}), 1,652(\mathrm{C}=\mathrm{O})$, and 1,604 $(\mathrm{C}=\mathrm{N}) .{ }^{1} \mathrm{H}$ NMR (acetone- $\left.\mathrm{d}_{6}\right) \delta(\mathrm{ppm}): 6.24(d, 1 \mathrm{H}, J=$ $15.39 \mathrm{~Hz}$, vinyl- $\left.\mathrm{C}_{2} \mathrm{H}\right), 6.80(d, 2 \mathrm{H}, J=8.64 \mathrm{~Hz}, 4-$ 
hydroxyphenyl $\left.\mathrm{C}_{3,5} \mathrm{H}\right), 7.24(d, 2 \mathrm{H}, J=8.62 \mathrm{~Hz}$, 4hydroxyphenyl $\left.\mathrm{C}_{2,6} \mathrm{H}\right), 7.46$ to $7.50\left(m, 3 \mathrm{H}\right.$, phenyl $\mathrm{C}_{3,4,5}$ $\mathrm{H}), 7.60$ to $7.66\left(m, 3 \mathrm{H}\right.$, quina- $\mathrm{C}_{6}$, phenyl $\left.\mathrm{C}_{2,6} \mathrm{H}\right), 7.73$ $\left(d, 1 \mathrm{H}, J=8.07 \mathrm{~Hz}\right.$, quina- $\left.\mathrm{C}_{8} \mathrm{H}\right), 7.81$ to $7.85(m, 1 \mathrm{H}$, quina- $\left.\mathrm{C}_{7} \mathrm{H}\right), 7.92\left(d, 1 \mathrm{H}, J=15.43 \mathrm{~Hz}\right.$, vinyl- $\left.\mathrm{C}_{1} \mathrm{H}\right), 8.02$ $(s, 1 \mathrm{H}, 4$-hydroxyphenyl - $\mathrm{OH}), 8.17(d, 1 \mathrm{H}, J=9.18 \mathrm{~Hz}$, quina- $\mathrm{C}_{5} \mathrm{H}$ ). Anal. calcd. for $\mathrm{C}_{22} \mathrm{H}_{18} \mathrm{~N}_{2} \mathrm{O}_{2}$ : C, 7.17; $\mathrm{H}$, 5.23; N, 8.18. Found: C, 76.86; H, 5.02; N, 8.38.

\section{(E)-2-(4-hydroxy-3-methoxystyryl)-3-o-tolylquinazolin-4(3H)- one (13)}

IR (Nujol) $\left(\mathrm{cm}^{-1}\right): 3,400(\mathrm{OH}), 1,683(\mathrm{C}=\mathrm{O}), 1,634$ $(\mathrm{C}=\mathrm{N}), 1,211$ and $1,148(\mathrm{C}-\mathrm{O}-\mathrm{C}) .{ }^{1} \mathrm{H} \mathrm{NMR}\left(\mathrm{CDCl}_{3}\right) \delta$ (ppm): $2.15\left(s, 3 \mathrm{H}, \quad\right.$-tolyl $\left.\mathrm{CH}_{3}\right), 3.80$ (s, 3H, 4hydroxy-2-methoxyphenyl -O- $\left.\mathrm{CH}_{3}\right), 6.10(s, 1 \mathrm{H}, 4$ hydroxy-2-methoxyphenyl -OH), $6.27(d, 1 \mathrm{H}, J=15.44$ $\mathrm{Hz}$, vinyl- $\left.\mathrm{C}_{2} \mathrm{H}\right), 6.88$ to 6.93 ( $m, 2 \mathrm{H}, 4$-hydroxy-2methoxyphenyl $\left.\mathrm{C}_{3,5} \mathrm{H}\right), 6.98(d, 1 \mathrm{H}, J=8.12 \mathrm{~Hz}, 4$ hydroxy-2-methoxyphenyl $\left.\mathrm{C}_{6} \mathrm{H}\right), 7.24(d, 1 \mathrm{H}, J=7.52$ $\mathrm{Hz}, o$-tolyl $\left.\mathrm{C}_{3} \mathrm{H}\right), 7.42$ to $7.53\left(m, 4 \mathrm{H}, o\right.$-tolyl $\mathrm{C}_{4,5,6} \mathrm{H}$ and quina- $\left.\mathrm{C}_{6} \mathrm{H}\right), 7.82\left(m, 2 \mathrm{H}\right.$, quina- $\left.\mathrm{C}_{7,8} \mathrm{H}\right), 7.96(d, 1 \mathrm{H}$, $J=15.48 \mathrm{~Hz}$, vinyl- $\left.\mathrm{C}_{1} \mathrm{H}\right), 8.34(d, 1 \mathrm{H}, J=7.884 \mathrm{~Hz}$, quina- $\mathrm{C}_{5} \mathrm{H}$ ). Anal. calcd. for $\mathrm{C}_{24} \mathrm{H}_{22} \mathrm{~N}_{2} \mathrm{O}_{3}$ : C, 74.59; H, 5.74; N, 7.23. Found: C, 74.28; H, 5.96; N, 7.56.

\section{Conclusions}

Some 3-aryl-2-(substitutedstyryl)-4(3H)-quinazolinone derivatives were synthesized and tested for their antileishamanial activities. Most of the synthesized compounds displayed better antileishmanial activities as compared to the standard drug miltefosine and lower antileishmanial activity as compared to amphotericin B deoxycholate except (E)-2-(4-chlorostyryl)-3-p-tolyl-4(3H)-quinazolinone (7). Compound 7 showed pronounced antileishmanial activities as compared to miltefosine and amphotericin $B$ deoxycholate. Thus, 2,3-disubstituted-4(3H)-quinazolinones containing an aromatic substitution at 3-position and substituted styryl moiety at 2-position represent a promising matrix for the development of antileishmanial agents.

\section{Competing interests}

The authors declare that they have no competing interests.

\section{Acknowledgements}

The authors are thankful to Prof. Wondimagegn Mammo for his considerable support in running and interpreting the ${ }^{1} \mathrm{H}$ NMR data. The following were acknowledged: The Department of Pharmaceutical Chemistry, Faculty of Pharmacy, Alexandria University for performing the elemental microanalysis and providing some chemicals, Debre Markos University for granting study leave to Mr. Yihenew, and Addis Ababa University for financially supporting this research work.

\footnotetext{
Author details

${ }^{1}$ Department of Chemistry, Natural and Computational Science College, Debre Markos University, Debre Markos, Ethiopia. ${ }^{2}$ Department of Pharmaceutical Chemistry, Alexandria University, Alexandria 21215, Egypt. ${ }^{3}$ Department of Pharmaceutical Chemistry and Pharmacognosy, School of Pharmacy, Addis Ababa University, Addis Ababa, Ethiopia.
}

Received: 25 May 2014 Accepted: 3 September 2014

Published online: 17 September 2014

\section{References}

1. Renslo AR, McKerrow JH (2006) Drug discovery and development for neglected parasitic diseases. Nat Chem Biol 2:701-710

2. McConville MJ, Souza D, Saunders E, Likic VA, Thomas N (2007) Living in a phagolysosome; metabolism of Leishmania amastigotes. Trends Parasitol 23:368-375

3. Sharma U, Singh S (2008) Insect vectors of Leishmania: distribution, physiology and their control. J Vector Borne Dis 45:255-272

4. Manandhar KD, Yadav TP, Prajapati VK, Kumar S, Rai M, Dube A, Srivastava ON, Sundar S (2008) Antileishmanial activity of nano-amphotericin B deoxycholate. J Antimicrob Chemother 62:376-380

5. Nascimento ET, Moura MLN, Queiroz JW, Barroso AW, Araujo AF, Rego EF, Wilson ME, Pearson RD, Jeronimo SM (2011) The emergence of concurrent HIV-1/AIDS and visceral leishmaniasis in Northeast Brazil. Trans R Soc Trop Med Hyg 105:298-300

6. Cenderello G, Pasa A, Dusi A, Dentone C, Toscanini F, Bobbio N, Bondi E, Bono VD, Izzo M, Riccio G, Anselmo M, Giacchino R, Marazzi MG, Pagano G, Cassola G, Viscoli C, Ferrea G, De Maria A (2013) Varied spectrum of clinical presentation and mortality in a prospective registry of visceral leishmaniasis in a low endemicity area of Northern Italy. BMC Infect Dis 13:248

7. Herremans T, Pinelli E, Casparie M, Nozari N, Roelfsema J, Kortbeek L (2010) Increase of imported leishmaniasis in the Netherlands: a twelve-year overview (1996-2007). Int Health 2:42-46

8. Ignatius R, Loddenkemper C, Woitzik J, Schneider T, Harms G (2011) Localized leishmanial lymphadenopathy: an unusual manifestation of leishmaniasis in a traveler in southern Europe. Vector-Borne Zoonotic Dis 11(8):1213-1215

9. Bray DP, Hamilton JGC (2013) Insecticide-impregnated netting as a potential tool for long-lasting control of the leishmaniasis vector Lutzomyia longipalpis in animal shelters. Parasites Vectors 6:133

10. Mascari TM, Stout RW, Foil LD (2012) Laboratory evaluation of oral treatment of rodents with systemic insecticides for control of blood feeding sand flies (Diptera: Psychodidae). Vector-Borne Zoonotic Dis 12(8):699-704

11. Chaves LF, Calzada JE, Rigg C, Valderrama A, Gottdenker NL, Saldaña A (2013) Leishmaniasis sand fly vector density reduction is less marked in destitute housing after insecticide thermal fogging. Parasites Vectors 6:164

12. Thakur CP, Kumar K (1992) Post kala-azar dermal leishmaniasis: a neglected aspect of kala-azar control programmes. Ann Trop Med Parasitol 86:355-359

13. Topuzogullari M, Koc RC, Isoglu SD, Bagirova M, Akdeste Z, Elcicek S, Oztel ON, Baydar SY, Ates SC, Allahverdiyev AM (2013) Conjugation, characterization and toxicity of lipophosphoglycan-polyacrylic acid conjugate for vaccination against leishmaniasis. J Biomed Sci 20:35

14. Kaur J, Kaur T, Kaur S (2011) Studies on the protective efficacy and immunogenicity of $\mathrm{Hsp} 70$ and $\mathrm{Hsp} 83$ based vaccine formulations in Leishmania donovani infected BALB/c mice. Acta Trop 119:50-56

15. Abdian N, Gholami E, Zahedifard F, Safaee N, Rafati S (2011) Evaluation of DNA/DNA and prime-boost vaccination using LPG3 against Leishmania major infection in susceptible BALB/C mice and its antigenic properties in human leishmaniasis. Experimental Parasitol 127:627-636

16. Salazara MBM, Domíngueza JD, Estradaa JS, Bonillab CG, Becker I (2014) Vaccination with Leishmania mexicana LPG induces PD-1 in CD8+ and PD-L2 in macrophages thereby suppressing the immune response: a model to assess vaccine efficacy. Vaccine 32:1259-1265

17. Carrión J, Folgueira C, Soto M, Fresno M, Requena JM (2011) Leishmania infantum HSP70-II null mutant as candidate vaccine against leishmaniasis: a preliminary evaluation. Parasites Vectors 4:150

18. Ait-Oudhia K, Gazanion E, Oury B, Vergnes B, Sereno D (2011) The fitness of antimony-resistant Leishmania parasites: lessons from the field. Trends Parasitol 27:141-142

19. Adam GK, Abdulla MA, Ahmed AA, Adam I (2009) Maternal and perinatal outcomes of visceral leishmaniasis (kala-azar) treated with sodium stibogluconate in eastern Sudan. Int J Gynecol Obstet 107:208-210

20. Dorlo TPC, Kager PA (2010) Comment on: cutaneous and mucocutaneous leishmaniasis in Tigray, northern Ethiopia: clinical aspects and therapeutic concerns. Trans R Soc Trop Med Hyg 104:84-85

21. Bray PG, Barrett MP, Ward SA, Koning HP (2003) Pentamidine uptake and resistance in pathogenic protozoa: past, present and future. Trends Parasitol 19:232-239 
22. Ben Salah A, Buffet PA, Morizot G, Ben Massoud N, Zaatour A, Ben Alaya N, Hamida NBH, El Ahmadi Z, Downs MT, Smith PL, Dellagi K, Grogl M (2009) WR279,396, a third generation aminoglycoside ointment for the treatment of Leishmania major cutaneous leishmaniasis: a phase 2, randomized, double blind, placebo-controlled study. PLoS Negl Trop Dis 3:e432

23. Sundar S, Sinha PK, Rai M, Verma DK, Nawin K, Alam S, Chakravarty J, Vaillant M, Verma N, Pandey K, Kumari P, Lal CS, Arora R, Sharma B, Ellis S, Strub-Wourgaft N, Balasegaram M, Olliaro P, Das P, Modabber F (2011) Comparison of short-course multidrug treatment with standard therapy for visceral leishmaniasis in India: an open-label, non-inferiority, randomised controlled trial. Lancet 377:477-486

24. Melaku Y, Collin SM, Keus K, Gatluak F, Ritmeijer K, Davidson RN (2007) Treatment of kala-azar in southern Sudan using a 17-day regimen of sodium stibogluconate combined with paromomycin: a retrospective comparison with 30-day sodium stibogluconate monotherapy. Am J Trop Med Hyg 77:89-94

25. Adib M, Ansari S, Mohammadi A, Bijanzadeh HR (2010) A novel, one-pot, solvent and catalyst-free synthesis of 2-aryl/alkyl-4(3H)-quinazolinones. Tetrahedron Lett 51:30-32

26. Kumar M, Sharma K, Sharma DK (2012) Diversity oriented one-pot three-component sequential synthesis of annulated benzothiazoloquinazolines. Org Med Chem Lett 2:10

27. Nouira I, Kostakis IK, Dubouilh C, Chosson E, lannelli M, Besson T (2008) Decomposition of formamide assisted by microwaves, a tool for synthesis of nitrogen-containing heterocycles. Tetrahedron Lett 49:7033-7036

28. Ye C, You J, Li XF, You R, Weng Y, Li J, Wang Y (2010) Design, synthesis and anticoccidial activity of a series of 3-(2-(2-methoxyphenyl)-2-oxoethyl) quinazolinone derivatives. Pestic Biochem Physiol 97:194-198

29. Omar MA, Conrad J, Beifuss U (2014) Copper-catalyzed domino reaction between 1-(2-halophenyl)methanamines and amidines or imidates for the synthesis of 2-substituted quinazolinones. Tetrahedron 70:3061-3072

30. Safaei HR, Shekouhy M, Shafiee V, Davoodi M (2013) Glycerol based ionic liquid with a borone core: a new highly efficient and reusable promoting medium for the synthesis of quinazolinones. J Mol Liq 180:139-144

31. Fischer C, Shah S, Hughes BL, Nikov GN, Crispino JL, Middleton RE, Szewczak AA, Munoz B, Shearman MS (2011) Quinazolinones as Y-secretase modulators. Bioorg Med Chem Lett 21:773-776

32. Manivannan E, Chaturvedi SC (2011) Analogue-based design, synthesis and molecular docking analysis of 2,3-diarylquinazolinones as non-ulcerogenic anti-inflammatory agents. Bioorg Med Chem 19:4520-4528

33. Rhee H-K, Yoo JH, Lee E, Kwon YJ, Seo H-R, Lee Y-S, Choo H-YP (2011) Synthesis and cytotoxicity of 2-phenylquinazolin-4(3H)-one derivatives. Eur J Med Chem 46:3900-3909

34. Jagani CL, Sojitra NA, Vanparia SF, Patel TS, Dixit RB, Dixit BC Microwave promoted synthesis and antimicrobial activity of 3-thiazole substituted 2-styryl-4(3H)-quinazolinone derivatives. J Saudi Chem Soc doi:10.1016/j. jscs.2011.02.001

35. Shivananda MK, Holla BS (2011) Antifungal activity studies of some quinazolinone derivatives. J Chem Pharm Res 3:83-86

36. Špulák M, Pourová J, Vopršálová M, Mikušek J, Kuneš J, Vacek J, Ghavre M, Gathergood N, Pour M (2014) Novel bronchodilatory quinazolines and quinoxalines: synthesis and biological evaluation. Eur J Med Chem 74:65-72

37. Berman JD, King M, Edwards N (1989) Antileishmanial activities of 2,4-diaminoquinazoline putative dihydrofolate reductase inhibitors. Antimicrobial Agents Chemother 33:1860-1863

38. Bhattacharjee AK, Skanchy DJ, Jennings B, Hudson TH, Brendle JJ, Werbovetz KA (2002) Analysis of stereoelectronic properties, mechanism of action and pharmacophore of synthetic indolo [2,1-b]quinazoline-6,12-dione derivatives in relation to antileishmanial activity using quantum chemical, cyclic voltammetry and 3-D-QSAR catalyst procedures. Bioorg Med Chem 10:1979-1989

39. Arfan M, Khan R, Khan MA, Anjum S, Choudhary MI, Ahmad M (2010) Synthesis and antileishmanial and antimicrobial activities of some 2,3-disubstituted 3H-quinazolin-4-ones. J Enzyme Inhib Med Chem 25:451-558

40. Fleita DH, Mohareb RM, Sakka OK (2013) Antitumor and antileishmanial evaluation of novel heterocycles derived from quinazoline scaffold: a molecular modeling approach. Med Chem Res 22:2207-2221

41. Lara O, Raquel E, María A, Juan J, Francisco B, José M (2007) In vitro effect of new formulations of amphotericin $B$ on amastigote and promastigote forms of Leishmania infantum. Int J Antimicrob Agents 30:325-329

42. Tariku Y, Hymete A, Hailu A, Rohloff J (2010) Essential-oil composition, antileishmanial and toxicity study of Artemisia abyssinica and Satureja punctata ssp. punctata from Ethiopia. Chem Biodivers 7:1013-1016
43. Lorke D (1983) A new approach to practical acute toxicity test. Arch Toxicol 54:275-286

44. Nakayama GR, Caton MC, Nova MP, Parandoosh Z (1997) Assessment of the Alamar Blue assay for cellular growth and viability in vitro. J Immunol Methods 204:205-208

45. Al-Nasiry S, Geusens N, Hanssens M, Luyten C, Pijnenborg R (2007) The use of Alamar Blue assay for quantitative analysis of viability, migration and invasion of choriocarcinoma cells. Hum Reprod 25:1-6

46. Shimony O, Jaffe CL (2006) Rapid fluorescent assay for screening drugs on Leishmania amastigotes. J Microbiol Methods 75:196-200

47. Kumar A, Sharma S, Bajaj K, Sharma S, Panwar H, Singh T, Srivastava VK (2003) Some new 2,3,6-trisubstituted quinazolinones as potent anti-inflammatory, analgesic and COX-II inhibitors. Bioorg Med Chem 11:5293-5299

48. Errede LA (1976) Acylanthranils 1. The pathway of quinazolone formation in the reaction of acylanthranils with anilines. J Org Chem 41:1763-1765

49. Raffa D, Edler MC, Daidone G, Maggio B, Merickech M, Plescia S, Schillaci D, Bai R, Hamel E (2004) Synthesis, cytotoxicity, and inhibitory effects on tubulin polymerization of a new 3-heterocyclo substituted 2styrylquinazolinones. Eur J Med Chem 39:299-304

doi:10.1186/s13588-014-0010-1

Cite this article as: Birhan et al:: Synthesis and antileishmanial evaluation of some 2,3-disubstituted-4(3H)-quinazolinone derivatives. Organic and Medicinal Chemistry Letters 2014 4:10.

\section{Submit your manuscript to a SpringerOpen ${ }^{\odot}$ journal and benefit from:}

- Convenient online submission

Rigorous peer review

- Immediate publication on acceptance

- Open access: articles freely available online

- High visibility within the field

- Retaining the copyright to your article

Submit your next manuscript at $>$ springeropen.com 